\title{
TYRO3 Truncation Resulting From a t(10;15)(p11;q15) Chromosomal Translocation in Pediatric Acute Myeloid Leukemia
}

\author{
MARTA BRUNETTI ${ }^{1}$, BERNWARD ZELLER $^{2}$, ANNE TIERENS ${ }^{3}$, SVERRE HEIM $^{1,4}$, \\ FRANCESCA MICCI ${ }^{1}$ and IOANNIS PANAGOPOULOS ${ }^{1}$ \\ ${ }^{1}$ Section for Cancer Cytogenetics, Institute for Cancer Genetics and Informatics, \\ The Norwegian Radium Hospital, Oslo University Hospital, Oslo, Norway; \\ ${ }^{2}$ Division of Pediatric and Adolescent Medicine, Oslo University Hospital Rikshospitalet, Oslo, Norway; \\ ${ }^{3}$ Laboratory Medicine Program, Department of Haematopathology, \\ University Health Network, Toronto, ON, Canada; \\ ${ }^{4}$ Institute of Clinical Medicine, Faculty of Medicine, University of Oslo, Oslo, Norway
}

\begin{abstract}
Background/Aim: Novel acquired chromosome aberrations in cancer may provide insights into pathogenetic mechanisms, be of diagnostic and/or prognostic significance and pave the way for new modes of therapeutic intervention. Here, we report a novel chromosome translocation and its molecular genetic consequences in a pediatric acute myeloid leukemia (AML) case. Materials and Methods: Cytogenetic, RNA sequencing, and molecular analyses were performed on the bone marrow cells of a child with AML. Results: The patient entered complete hematologic remission after treatment according to the NOPHO-AML 2004 protocol. A novel t(10;15)(p11;q15) translocation was found in leukemic cells at diagnosis resulting in a fusion of exon 13 of TYRO3 with a sequence from 10p11. The transcript codes for a putative TYRO3 protein lacking the tyrosine kinase domain. Conclusion: The t $(10 ; 15)(p 11 ; q 15)$ translocation in neoplastic bone marrow cells results in truncated TYRO3. Because the role of the truncated TYRO3 cannot be predicted functional studies are required.
\end{abstract}

Acute myeloid leukemia (AML) is a heterogeneous hematologic malignancy characterized by clonal expansion

This article is freely accessible online.

Correspondence to: Ioannis Panagopoulos, Section for Cancer Cytogenetics, Institute for Cancer Genetics and Informatics, The Norwegian Radium Hospital, Oslo University Hospital, Montebello, PO Box 4954 Nydalen, NO-0424 Oslo, Norway. Tel: +47 22782362, e-mail: ioannis.panagopoulos@rr-research.no

Key Words: Pediatric, acute myeloid leukemia, chromosome translocation, RNA sequencing, TYRO3 gene. of abnormal myeloid precursors and accounts for $15 \%$ of all pediatric leukemias $(1,2)$. For the classification of AML, integration of morphology, immunophenotype, cytogenetic analysis, and molecular genetics are required (3-8).

Because chromosome abnormalities acquired by the leukemic cells have been shown to be remarkable diagnostic and prognostic parameters (9-11), the cytogenetic examination of bone marrow cells is now an indispensable component of the clinical management of patients with hematological malignancies, including AML. Sometimes, cytogenetic information is decisive in the choice of optimal treatment for AML-patients as illustrated by the finding at diagnosis of the chromosomal translocation $\mathrm{t}(15 ; 17)(\mathrm{q} 24 ; \mathrm{q} 11)$, the hallmark of acute promyelocytic leukemia (APL), which is treated and monitored differently from other AML subtypes (12-14).

The detection of acquired chromosomal abnormalities in leukemic cells, in particular translocations and inversions, has helped identify breakpoint genes that, when rearranged or otherwise deregulated, launch or contribute to the leukemogenic process (15). Numerous pathogenetic or genetic subgroups have thus been identified (15). Nevertheless, new recurrent or unique chromosome aberrations (mainly balanced translocations) corresponding to smaller cytogenetic subgroups continue to be reported in AML and myelodysplasia (MDS) (16-19). The subsequent description of additional cases carrying the same genetic abnormality is far from uncommon. This establishes the acquired aberration in question as a recurrent change, and may help determine its prognostic significance, as well as offers the opportunity to probe further the mechanisms of leukemogenesis in patients with these rare abnormalities. By way of example, the $\mathrm{t}(7 ; 21)(\mathrm{p} 22 ; \mathrm{q} 22)$, which generates the RUNX1-USP42 fusion gene, was originally found in a 7-year-old boy with minimally differentiated AML (AML-M0) (20). Today, 
$\mathrm{t}(7 ; 21)(\mathrm{p} 22 ; \mathrm{q} 22) / R U N X 1-U S P 42$ is acknowledged as a rare but non-random genomic aberration of myeloid malignancies, where it frequently occurs together with del(5q) (20-25).

We report here a $t(10 ; 15)(p 11 ; q 15)$ chromosomal translocation in a case of pediatric AML. The translocation caused fusion of the TYRO3 gene with a non-genic sequence from 10p11 leading to the generation of a putative truncated TYRO3 protein.

\section{Materials and Methods}

Ethics statement. The study was approved by the regional ethics committee (Regional komité for medisinsk forskningsetikk Sør-Øst, Norge, 2010/1389/REK sør-øst A). Written informed consent was obtained. The Ethics Committee's approval included a review of the consent procedure. All patient information has been de-identified.

Case history. A seven years eight months old boy presented with fatigue developed over several weeks and a weight loss of $1.5 \mathrm{~kg}$. Physical examination revealed hepatosplenomegaly and enlarged cervical, axillary, and inguinal lymph nodes. Tests showed a white blood cell count of $127 \times 10^{9} / 1$, a platelet count of $70 \times 10^{9} / 1$, and a hemoglobin value of $11.2 \mathrm{~g} / \mathrm{dl}$.

A bone marrow investigation revealed $60 \%$ myeloblasts and an overall morphological picture corresponding to myelomonocytic leukemia or AML-M4. Immunophenotyping confirmed the diagnosis of AML-M4 with myelomonocytic cells representing 93\%. Chromosome analysis (see also below) of G-banded bone marrow preparations revealed a $\mathrm{t}(10 ; 15)(\mathrm{p} 11 ; \mathrm{q} 15)$ chromosomal translocation. There were no signs of extramedullary leukemia (CNS involvement, myelosarcomas).

The boy was treated according to the NOPHO-AML 2004 protocol (26) $(\mathrm{NOPHO}=$ Nordic Society of Paediatric Haematology and Oncology) with six chemotherapy courses: AIET (cytarabineidarubicin-etoposide-thioguanin), AM (cytarabine-mitoxantrone), HA1M (high dose cytarabine 1 g-mitoxantrone), HA2E (cytarabine 2 g-etoposide), HA3 (cytarabine $3 \mathrm{~g}$ ), and HA2E (cytarabine 2 getoposide). After completion of the courses, the patient was randomized to the non-GO arm (no additional therapy with gentuzumabotogamizin). Treatment was uneventful except for expected side effects such as mucositis and repeated infections due to severe cytopenia.

The patient has been healthy and relapse-free for ten years after cessation of treatment. There have not been any signs of late effects at regular follow-ups.

G-banding and karyotyping. Bone marrow cells were cytogenetically investigated as part of our diagnostic routine by standard methods (27). Chromosome preparations were made from metaphase cells of a 24-h culture, G-banded using Leishman's stain and karyotyped according to the International System for Human Cytogenomic Nomenclature (ISCN, 2016) guidelines (28).

Molecular genetic analyses. Total RNA was extracted from bone marrow at the time of diagnosis using miRNeasy (Qiagen, Hilden, Germany) and QIAcube (Qiagen). The RNA quality was evaluated using 2100 Bioanalyzer (Agilent, Santa Clara, CA, USA) according to the manufacturer's instructions. Three $\mu \mathrm{g}$ of total RNA were sent for high-throughput paired-end RNA-sequencing at the Norwegian Sequencing Centre, Ullevål Hospital, Oslo, Norway. Detailed information about these analyses has been given elsewhere (29). A total of 104 million reads were obtained. FASTQC software was used for quality control of the raw sequence data. TopHat-Fusion software was used for the detection of fusion transcripts $(30,31)$.

One $\mu \mathrm{g}$ of total RNA was reverse-transcribed in a $20 \mu$ reaction volume using iScript Advanced cDNA synthesis Kit for Reverse Transcriptase Polymerase Chain Reaction (RT-PCR) according to the manufacturer's instructions (Bio-Rad, Hercules, CA, USA). For the detection of the TYRO3 fusion transcript, the primer combination TYRO3-1730F1 (5'-GGGCATCAGCGATGAACTAAAGGA-3') and 10p11R1 (5'-CGAATCCCACCACCAGCATCAC-3') was used. PCR amplification was performed on a C-1000 Thermal cycler (Bio-Rad) with an initial denaturation at $94^{\circ} \mathrm{C}$ for $30 \mathrm{~s}$ followed by 35 cycles at $98^{\circ} \mathrm{C}$ for $7 \mathrm{~s}, 68^{\circ} \mathrm{C}$ for $2 \mathrm{~min}$, and a final extension at $68^{\circ} \mathrm{C}$ for $5 \mathrm{~min}$. Three $\mu$ of the PCR product were stained with GelRed (Biotium, Hayward, CA, USA), analyzed by electrophoresis through $1.0 \%$ agarose gel, and photographed. The remaining PCR products were purified using the QIAquick PCR Purification Kit (Qiagen) and sequenced at Eurofins GATC Biotech (Cologne, Germany). The basic local alignment search tool (BLAST) software was used for computer analysis of sequence data (32). The BLAST alignment tool and the human genome browser at UCSC were also used to map the sequences on the Human GRCh37/hg19 assembly (33).

\section{Results}

G-Banding analysis of bone marrow cells at diagnosis yielded the karyotype 46,XY, t(10;15)(p11;q15)[8]/46,XY[2] (Figure 1A). Using the TopHat-Fusion on the raw sequencing data a fusion was found between exon 13 of the TYRO3 gene from 15 q15 (nucleotide 1896 on the sequence with the accession number NM_006293.4) and a non-genic sequence mapping to 10p11: GAAGCAAGAGGATGGCTCCTTTGTGAAAGTG GCTGTGAAGATGCTGAAAG/ATGAAACATGAGCAAAA ACAGGGAAATGGAGACCTGGAAAAGAGAGGGCA. RTPCR with the specific primer combination TYRO31730F1/10p11R1 confirmed the presence of the TYRO3-fusion transcript (Figure 1B).

\section{Discussion}

We present a case of pediatric AML-M4 in which the leukemic cells had a novel $\mathrm{t}(10 ; 15)(\mathrm{p} 11 ; \mathrm{q} 15)$ chromosome translocation as the sole cytogenetic abnormality. The molecular analysis of the translocation showed that it resulted in rearrangement of the TYRO3 gene from $15 \mathrm{q} 15$.

TYRO3, together with the genes encoding the AXL receptor tyrosine kinase ( $A X L$ on $19 \mathrm{q} 13.2)$ and the MER proto-oncogene tyrosine kinase (MERTK on 2q13), constitute the TAM family of receptor tyrosine kinases (RTK) (34-36). Like all RTK, TYRO3, AXL, and MER are transmembrane proteins that transduce signals from the extracellular environment to the cytoplasm and nucleus, regulating a wide range of normal cellular processes that include cell survival, growth, differentiation, adhesion, and motility (34). 
A

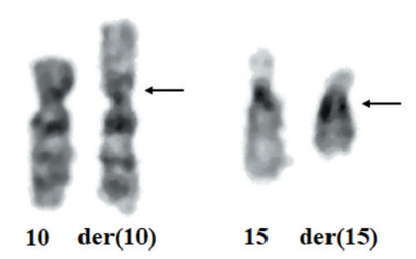

B

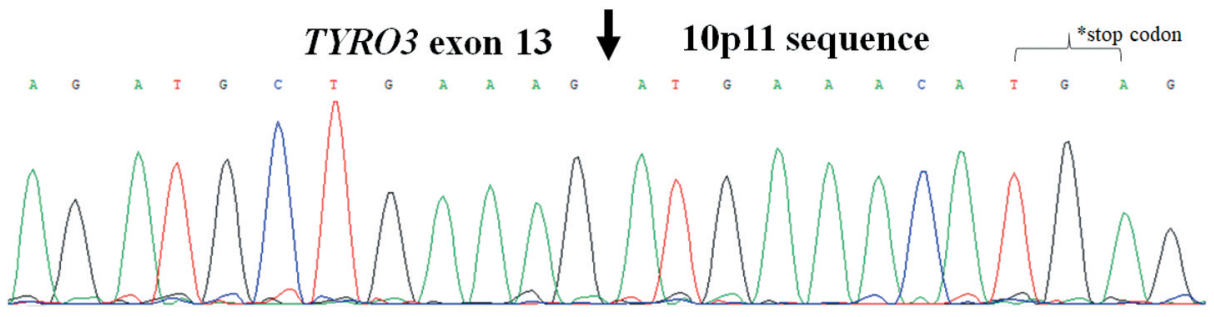

C
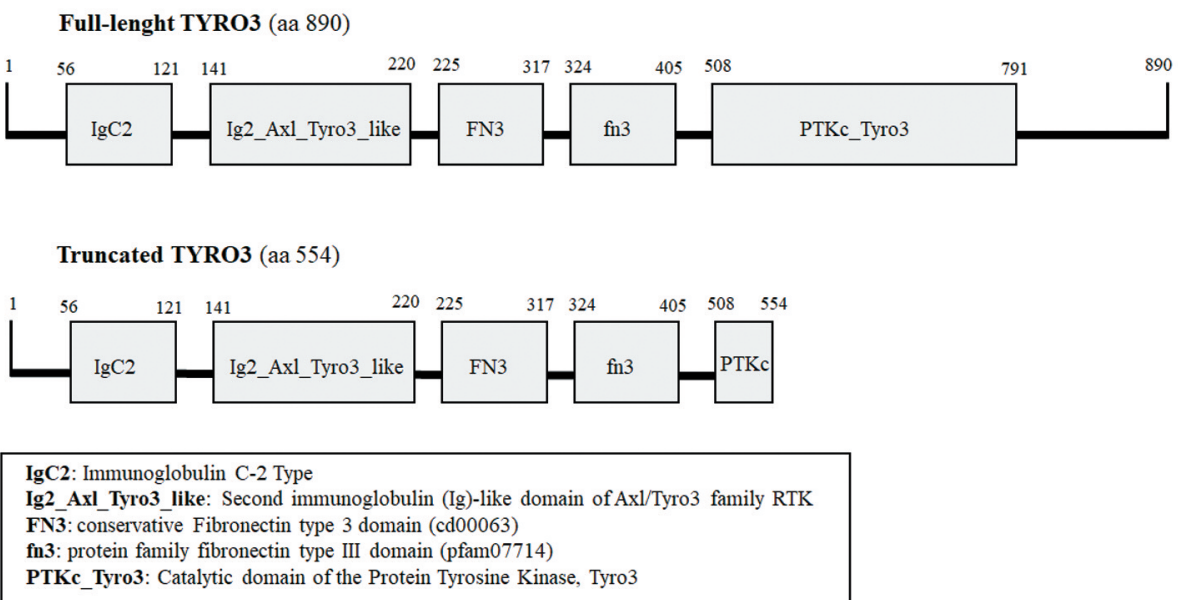

Figure 1. Genetic analyses of the pediatric acute myeloid leukemia. A) Partial karyotype showing $(10 ; 15)($ p11;q15) chromosomal translocation; B) Partial sequence chromatogram of the amplified cDNA fragment showing the fusion point of the TYRO3 (exon 13) and a short sequence mapping on chromosome 10p11. C) Illustration of the full-length and truncated TYRO3 protein. All domains and amino acids numbers are shown.

Overexpression of TAM family kinases occurs in many human cancers, including leukemia, glioma, colorectal carcinoma, breast cancer, gastrointestinal stromal tumor, hepatocellular carcinoma, melanoma, pancreatic adenocarcinoma, and prostate cancer $(35,37-39)$. Compared to MERTK and $A X L$, less is known about TYRO3 (40), although TYRO3 mutations have been reported in human malignancies $(40,41)$. Missense mutations within the kinase domain have been reported in colon cancer, lung cancer, melanoma, brain cancer, and AML (34). Premature stop codon mutations have been described in melanoma and lung cancer $(40,42,43)$. Because functional studies have not been performed, the significance of these mutations is currently unknown (40). Furthermore, elevated expression of TYRO3 has been found in several cancers, including leukemic cells (40).

The present study is the first to demonstrate rearrangement and disruption of TYRO3 in a hematologic malignancy stemming from the chromosomal translocation $\mathrm{t}(10 ; 15)(\mathrm{p} 11 ; \mathrm{q} 15)$. Molecular analysis of the translocation showed fusion of TYRO3 with a non-genic sequence from 10p11, resulting in an abrogated TYRO3 and a 554 aa putative TYRO3 truncated protein (Figure 1C). This protein would contain the extracellular domain with the two immunoglobulin domains, the two fibronectin type III domains, and the transmembrane domain. It will lack the catalytic domain of the protein tyrosine kinase TYRO3, the autophosphorylation sites, and the carboxyl-terminal part, which is required for maintaining TYRO3 stability $(44,45)$. The precise 
role of TYRO3 truncated protein in the development of leukemia cannot be predicted without functional studies. However, an anomaly in signal transduction can be assumed. Alternatively, loss of a functional TYRO3 allele may contribute to leukemogenesis.

Chromosomal translocations are common in cancer and typically generate transforming oncogenes by fusing genes or by inducing overexpression of one or more genes near the breakpoints (15). However, translocations resulting in gene truncations have also been reported (46-51). These typically replace or delete long 3'-untranslated genomic regions that contain regulatory sequences such as miRNAand AU-rich sequences. Alternatively, they may generate a premature stop codon in the open reading frames, thus acting as nonsense mutations and leading to the expression of C-terminal-truncated forms of the proteins (52-59).

Truncated RUNX1 proteins have been found to function as inhibitors of the normal RUNX1 protein, increase proliferation, and disrupt the cells' differentiation program (52-54). In a recent study, truncated RUNX1 protein has also been found to induce expression of the granulocyte colonystimulating factor (G-CSF) receptor on 32D myeloid leukemia cells (59). Truncated forms of ETV6 have been shown to have a dominant-negative effect on normal ETV6 function and disrupt both primitive and definitive hematopoiesis in the zebrafish model (60).

In the Mitelman Database of Chromosome Aberrations and Gene Fusions in Cancer (61), 89 cases of AML are listed with breakpoints in the chromosome band $15 \mathrm{q} 15$ where TYRO3 maps. Eight of them were myelomonocytic AMLs, the same type of AML as the one in the present case. It is possible that TYRO3 could have been pathogenetically involved in these leukemias.

\section{Conflicts of Interest}

The Authors declare that no potential conflicts of interest exist in relation to this study.

\section{Authors' Contributions}

MB performed molecular genetic experiments, evaluated the data, and drafted the manuscript. BZ made clinical evaluations and treated the patient. AT made the immunophenotypic investigation. SH evaluated the data and assisted with the writing of the manuscript. FM made cytogenetic examination and evaluated the data. IP designed and supervised the experiments, performed bioinformatics analysis, molecular genetic experiments, evaluated the data, and drafted the manuscript. All Authors read and approved the final manuscript.

\section{Acknowledgements}

This work was supported by grants from Radiumhospitalets Legater.

\section{References}

1 Lonetti A, Pession A and Masetti R: Targeted therapies for pediatric aml: Gaps and perspective. Front Pediatr 7: 463, 2019. PMID: 31803695. DOI: 10.3389/fped.2019.00463

2 Winer ES and Stone RM: Novel therapy in acute myeloid leukemia (aml): Moving toward targeted approaches. Ther Adv Hematol 10: 2040620719860645, 2019. PMID: 31321011. DOI: $10.1177 / 2040620719860645$

3 Papaemmanuil E, Gerstung M, Bullinger L, Gaidzik VI, Paschka P, Roberts ND, Potter NE, Heuser M, Thol F, Bolli N, Gundem G, Van Loo P, Martincorena I, Ganly P, Mudie L, McLaren S, O'Meara S, Raine K, Jones DR, Teague JW, Butler AP, Greaves MF, Ganser A, Döhner K, Schlenk RF, Döhner H and Campbell PJ: Genomic classification and prognosis in acute myeloid leukemia. N Engl J Med 374(23): 2209-2221, 2016. PMID: 27276561. DOI: 10.1056/NEJMoa1516192

4 Arber DA, Orazi A, Hasserjian R, Thiele J, Borowitz MJ, Le Beau MM, Bloomfield CD, Cazzola M and Vardiman JW: The 2016 revision to the world health organization classification of myeloid neoplasms and acute leukemia. Blood 127(20): 23912405, 2016. PMID: 27069254. DOI: 10.1182/blood-2016-03643544

5 Moarii $\mathrm{M}$ and Papaemmanuil E: Classification and risk assessment in AML: Integrating cytogenetics and molecular profiling. Hematology Am Soc Hematol Educ Program 2017(1): 37-44, 2017. PMID: 29222235. DOI: 10.1182/asheducation2017.1.37

6 Tyner JW, Tognon CE, Bottomly D, Wilmot B, Kurtz SE, Savage SL, Long N, Schultz AR, Traer E, Abel M, Agarwal A, Blucher A, Borate U, Bryant J, Burke R, Carlos A, Carpenter R, Carroll J, Chang BH, Coblentz C, d'Almeida A, Cook R, Danilov A, Dao KT, Degnin M, Devine D, Dibb J, Edwards DKt, Eide CA, English I, Glover J, Henson R, Ho H, Jemal A, Johnson K, Johnson R, Junio B, Kaempf A, Leonard J, Lin C, Liu SQ, Lo P, Loriaux MM, Luty S, Macey T, MacManiman J, Martinez J, Mori M, Nelson D, Nichols C, Peters J, Ramsdill J, Rofelty A, Schuff R, Searles R, Segerdell E, Smith RL, Spurgeon SE, Sweeney T, Thapa A, Visser C, Wagner J, Watanabe-Smith K, Werth K, Wolf J, White L, Yates A, Zhang H, Cogle CR, Collins RH, Connolly DC, Deininger MW, Drusbosky L, Hourigan CS, Jordan CT, Kropf P, Lin TL, Martinez ME, Medeiros BC, Pallapati RR, Pollyea DA, Swords RT, Watts JM, Weir SJ, Wiest DL, Winters RM, McWeeney SK and Druker BJ: Functional genomic landscape of acute myeloid leukaemia. Nature 562(7728): 526531, 2018. PMID: 30333627. DOI: 10.1038/s41586-018-0623-Z

7 Bolouri H, Farrar JE, Triche T, Jr., Ries RE, Lim EL, Alonzo TA, Ma Y, Moore R, Mungall AJ, Marra MA, Zhang J, Ma X, Liu Y, Liu Y, Auvil JMG, Davidsen TM, Gesuwan P, Hermida LC, Salhia B, Capone S, Ramsingh G, Zwaan CM, Noort S, Piccolo SR, Kolb EA, Gamis AS, Smith MA, Gerhard DS and Meshinchi S: The molecular landscape of pediatric acute myeloid leukemia reveals recurrent structural alterations and age-specific mutational interactions. Nat Med 24(1): 103-112, 2018. PMID: 29227476. DOI: 10.1038/nm.4439

8 McNeer NA, Philip J, Geiger H, Ries RE, Lavallée VP, Walsh M, Shah M, Arora K, Emde AK, Robine N, Alonzo TA, Kolb EA, Gamis AS, Smith M, Gerhard DS, Guidry-Auvil J, Meshinchi S and Kentsis A: Genetic mechanisms of primary chemotherapy resistance in pediatric acute myeloid leukemia. 
Leukemia 33(8): 1934-1943, 2019. PMID: 30760869. DOI: 10.1038/s41375-019-0402-3

9 Lazarevic VL and Johansson B: Why classical cytogenetics still matters in acute myeloid leukemia. Expert Rev Hematol 13(2): 9597, 2020. PMID: 31903786. DOI: 10.1080/17474086.2020.1711733

10 Döhner H, Estey EH, Amadori S, Appelbaum FR, Büchner T, Burnett AK, Dombret H, Fenaux P, Grimwade D, Larson RA, Lo-Coco F, Naoe T, Niederwieser D, Ossenkoppele GJ, Sanz MA, Sierra J, Tallman MS, Löwenberg B and Bloomfield CD: Diagnosis and management of acute myeloid leukemia in adults: Recommendations from an international expert panel, on behalf of the european leukemianet. Blood 115(3): 453-474, 2010. PMID: 19880497. DOI: 10.1182/blood-2009-07-235358

11 Creutzig U, van den Heuvel-Eibrink MM, Gibson B, Dworzak MN, Adachi S, de Bont E, Harbott J, Hasle H, Johnston D, Kinoshita A, Lehrnbecher T, Leverger G, Mejstrikova E, Meshinchi S, Pession A, Raimondi SC, Sung L, Stary J, Zwaan CM, Kaspers GJ and Reinhardt D: Diagnosis and management of acute myeloid leukemia in children and adolescents: Recommendations from an international expert panel. Blood 120(16): 3187-3205, 2012. PMID: 22879540. DOI: 10.1182/blood-2012-03-362608

12 Jimenez JJ, Chale RS, Abad AC and Schally AV: Acute promyelocytic leukemia (apl): A review of the literature. Oncotarget 11(11): 992-1003, 2020. PMID: 32215187. DOI: 10.18632/oncotarget.27513

13 Sanz MA, Fenaux P, Tallman MS, Estey EH, Löwenberg B, Naoe T, Lengfelder E, Döhner H, Burnett AK, Chen SJ, Mathews V, Iland H, Rego E, Kantarjian H, Adès L, Avvisati G, Montesinos P, Platzbecker U, Ravandi F, Russell NH and LoCoco F: Management of acute promyelocytic leukemia: Updated recommendations from an expert panel of the european leukemianet. Blood 133(15): 1630-1643, 2019. PMID: 30803991. DOI: 10.1182/blood-2019-01-894980

14 Conneely SE and Stevens AM: Advances in pediatric acute promyelocytic leukemia. Children (Basel) 7(2), 2020. PMID: 32024232. DOI: $10.3390 /$ children7020011

15 Heim S and Miltelman F: Cancer cytogenetics: Chromosomal and molecular genetic abberations of tumor cells. Forth Edition edn. Wiley-Blackwell (ed.), 2015.

16 Cheng CK, Wong THY, Wan TSK, Wang AZ, Chan NPH, Chan NCN, Li CK and Ng MHL: Runx1 upregulation via disruption of long-range transcriptional control by a novel $\mathrm{t}(5 ; 21)(\mathrm{q} 13 ; \mathrm{q} 22)$ translocation in acute myeloid leukemia. Mol Cancer 17(1): 133, 2018. PMID: 30157851. DOI: 10.1186/s12943-018-0881-2

17 Panagopoulos I, Torkildsen S, Gorunova L, Ulvmoen A, Tierens A, Zeller B and Heim S: Runx1 truncation resulting from a cryptic and novel $\mathrm{t}(6 ; 21)(\mathrm{q} 25 ; \mathrm{q} 22)$ chromosome translocation in acute myeloid leukemia: A case report. Oncol Rep 36(5): 24812488, 2016. PMID: 27667292. DOI: 10.3892/or.2016.5119

18 Panagopoulos I, Gorunova L, Andersen HK, Bergrem A, Dahm A, Andersen K, Micci F and Heim S: Pan3-psma2 fusion resulting from a novel $\mathrm{t}(7 ; 13)(\mathrm{p} 14 ; \mathrm{q} 12)$ chromosome translocation in a myelodysplastic syndrome that evolved into acute myeloid leukemia. Exp Hematol Oncol 7: 7, 2018. PMID: 29560286. DOI: 10.1186/s40164-018-0099-4

19 Panagopoulos I, Gorunova L, Jacobsen EM, Andersen K, Micci $\mathrm{F}$ and Heim S: Runx1-pdcd6 fusion resulting from a novel $\mathrm{t}(5 ; 21)(\mathrm{p} 15 ; \mathrm{q} 22)$ chromosome translocation in myelodysplastic syndrome secondary to chronic lymphocytic leukemia. PLoS
One 13(4): e0196181, 2018. PMID: 29672642. DOI: 10.1371/journal.pone.0196181

20 Paulsson K, Békássy AN, Olofsson T, Mitelman F, Johansson B and Panagopoulos I: A novel and cytogenetically cryptic t(7;21)(p22;q22) in acute myeloid leukemia results in fusion of runx 1 with the ubiquitin-specific protease gene usp42. Leukemia 20(2): 224-229, 2006. PMID: 16357831. DOI: 10.1038/sj.leu.2404076

21 Foster N, Paulsson K, Sales M, Cunningham J, Groves M, O'Connor N, Begum S, Stubbs T, McMullan DJ, Griffiths M, Pratt $\mathrm{N}$ and Tauro S: Molecular characterisation of a recurrent, semi-cryptic runx 1 translocation $\mathrm{t}(7 ; 21)$ in myelodysplastic syndrome and acute myeloid leukaemia. Br J Haematol 148(6): 938-943, 2010. PMID: 25298786. DOI: 10.1111/j.13652141.2009.08039.x

22 Jeandidier E, Gervais C, Radford-Weiss I, Zink E, Gangneux C, Eischen A, Galoisy AC, Helias C, Dano L, Cammarata O, Jung G, Harzallah I, Guérin E, Martzolff L, Drénou B, Lioure B, Tancrédi C, Rimelen V and Mauvieux L: A cytogenetic study of 397 consecutive acute myeloid leukemia cases identified three with a $t(7 ; 21)$ associated with $5 q$ abnormalities and exhibiting similar clinical and biological features, suggesting a new, rare acute myeloid leukemia entity. Cancer Genet 205(7-8): 365-372, 2012. PMID: 22867997. DOI: 10.1016/j.cancergen.2012.04.007

23 Panagopoulos I, Gorunova L, Brandal P, Garnes M, Tierens A and Heim S: Myeloid leukemia with $\mathrm{t}(7 ; 21)(\mathrm{p} 22 ; \mathrm{q} 22)$ and $5 \mathrm{q}$ deletion. Oncol Rep 30(4): 1549-1552, 2013. PMID: 23877199. DOI: $10.3892 /$ or.2013.2623

24 Paulraj P, Diamond S, Razzaqi F, Ozeran JD, Longhurst M, Andersen EF, Toydemir RM and Hong B: Pediatric acute myeloid leukemia with $\mathrm{t}(7 ; 21)(\mathrm{p} 22 ; \mathrm{q} 22)$. Genes Chromosomes Cancer 58(8): 551-557, 2019. PMID: 30706625 . DOI: $10.1002 /$ gcc. 22740

25 Ji J, Loo E, Pullarkat S, Yang L and Tirado CA: Acute myeloid leukemia with $\mathrm{t}(7 ; 21)(\mathrm{p} 22 ; \mathrm{q} 22)$ and $5 \mathrm{q}$ deletion: A case report and literature review. Exp Hematol Oncol 3: 8, 2014. PMID: 24646765. DOI: 10.1186/2162-3619-3-8

26 Hasle H, Abrahamsson J, Forestier E, Ha SY, Heldrup J, Jahnukainen K, Jónsson Ó G, Lausen B, Palle J and Zeller B: Gemtuzumab ozogamicin as postconsolidation therapy does not prevent relapse in children with aml: Results from nopho-aml 2004. Blood 120(5): 978-984, 2012. PMID: 22730539. DOI: 10.1182/blood-2012-03-416701

27 Czepulkowski B: Basic techniques for the preparation and analysis of chromosomes from bone marrow and leukaemic blood. In: Human cytogenetics: Malignancy and acquired abnormalities. (Rooney DE ed.) New York: Oxford University Press, pp. 1-26, 2001.

28 McGowan-Jordan J, Simons A and Schmid M: An international system for human cytogenomic nomenclature (2016), ISCN 2016. S. Karger, 2016.

29 Torkildsen S, Gorunova L, Beiske K, Tjønnfjord GE, Heim S and Panagopoulos I: Novel zeb2-bcl11b fusion gene identified by rna-sequencing in acute myeloid leukemia with $\mathrm{t}(2 ; 14)(\mathrm{q} 22 ; \mathrm{q} 32)$. PLoS One 10(7): e0132736, 2015. PMID: 26186352. DOI: 10.1371/journal.pone. 0132736

30 Kim D and Salzberg SL: Tophat-fusion: An algorithm for discovery of novel fusion transcripts. Genome Biol 12(8): R72, 2011. PMID: 21835007. DOI: 10.1186/gb-2011-12-8-r72

31 Kim D, Pertea G, Trapnell C, Pimentel H, Kelley R and Salzberg SL: Tophat2: Accurate alignment of transcriptomes in the presence of insertions, deletions and gene fusions. Genome Biol 
14(4): R36, 2013. PMID: 23618408. DOI: 10.1186/gb-2013-144-r36

32 Altschul SF, Gish W, Miller W, Myers EW and Lipman DJ: Basic local alignment search tool. J Mol Biol 215(3): 403-410, 1990. PMID: 2231712. DOI: 10.1016/s0022-2836(05)80360-2

33 Kent WJ: Blat - the blast-like alignment tool. Genome Res 12(4): 656-664, 2002. PMID: 11932250. DOI: 10.1101/gr.229202

34 Linger RM, Keating AK, Earp HS and Graham DK: Tam receptor tyrosine kinases: Biologic functions, signaling, and potential therapeutic targeting in human cancer. Adv Cancer Res 100: 35-83, 2008. PMID: 18620092. DOI: 10.1016/s0065$230 x(08) 00002-x$

35 Graham DK, DeRyckere D, Davies KD and Earp HS: The tam family: Phosphatidylserine sensing receptor tyrosine kinases gone awry in cancer. Nat Rev Cancer 14(12): 769-785, 2014. PMID: 25568918. DOI: $10.1038 / \mathrm{nrc} 3847$

36 Lemke G: Biology of the tam receptors. Cold Spring Harb Perspect Biol 5(11): a009076, 2013. PMID: 24186067. DOI: 10.1101/cshperspect.a009076

37 Graham DK, Dawson TL, Mullaney DL, Snodgrass HR and Earp HS: Cloning and mrna expression analysis of a novel human protooncogene, c-mer. Cell Growth Differ 5(6): 647-657, 1994. PMID: 8086340.

38 Hong CC, Lay JD, Huang JS, Cheng AL, Tang JL, Lin MT, Lai GM and Chuang SE: Receptor tyrosine kinase axl is induced by chemotherapy drugs and overexpression of axl confers drug resistance in acute myeloid leukemia. Cancer Lett 268(2): 314324, 2008. PMID: 18502572. DOI: 10.1016/j.canlet.2008.04.017

39 Crosier PS, Hall LR, Vitas MR, Lewis PM and Crosier KE: Identification of a novel receptor tyrosine kinase expressed in acute myeloid leukemic blasts. Leuk Lymphoma 18(5-6): 443449, 1995. PMID: 8528051. DOI: 10.3109/10428199509059643

40 Smart SK, Vasileiadi E, Wang X, DeRyckere D and Graham DK: The emerging role of tyro3 as a therapeutic target in cancer. Cancers (Basel) 10(12), 2018. PMID: 30501104. DOI: 10.3390/cancers 10120474

41 Tate JG, Bamford S, Jubb HC, Sondka Z, Beare DM, Bindal N, Boutselakis H, Cole CG, Creatore C, Dawson E, Fish P, Harsha B, Hathaway C, Jupe SC, Kok CY, Noble K, Ponting L, Ramshaw CC, Rye CE, Speedy HE, Stefancsik R, Thompson SL, Wang S, Ward S, Campbell PJ and Forbes SA: Cosmic: The catalogue of somatic mutations in cancer. Nucleic acids research $47(D 1)$ : D941-D947, 2019. PMID: 30371878. DOI: 10.1093/nar/gky 1015

42 Easty DJ, Ganz SE, Farr CJ, Lai C, Herlyn M and Bennett DC: Novel and known protein tyrosine kinases and their abnormal expression in human melanoma. J Invest Dermatol 101(5): 679684, 1993. PMID: 8228328. DOI: 10.1111/1523-1747.ep12371675

43 Ding L, Getz G, Wheeler DA, Mardis ER, McLellan MD, Cibulskis K, Sougnez C, Greulich H, Muzny DM, Morgan MB, Fulton L, Fulton RS, Zhang Q, Wendl MC, Lawrence MS, Larson DE, Chen K, Dooling DJ, Sabo A, Hawes AC, Shen H, Jhangiani SN, Lewis LR, Hall O, Zhu Y, Mathew T, Ren Y, Yao J, Scherer SE, Clerc K, Metcalf GA, Ng B, Milosavljevic A, GonzalezGaray ML, Osborne JR, Meyer R, Shi X, Tang Y, Koboldt DC, Lin L, Abbott R, Miner TL, Pohl C, Fewell G, Haipek C, Schmidt H, Dunford-Shore BH, Kraja A, Crosby SD, Sawyer CS, Vickery T, Sander S, Robinson J, Winckler W, Baldwin J, Chirieac LR, Dutt A, Fennell T, Hanna M, Johnson BE, Onofrio RC, Thomas RK, Tonon G, Weir BA, Zhao X, Ziaugra L, Zody MC, Giordano T, Orringer MB, Roth JA, Spitz MR, Wistuba, II, Ozenberger B,
Good PJ, Chang AC, Beer DG, Watson MA, Ladanyi M, Broderick S, Yoshizawa A, Travis WD, Pao W, Province MA, Weinstock GM, Varmus HE, Gabriel SB, Lander ES, Gibbs RA, Meyerson M and Wilson RK: Somatic mutations affect key pathways in lung adenocarcinoma. Nature 455(7216): 1069-1075, 2008. PMID: 18948947 . DOI: $10.1038 /$ nature 07423

44 Lai C, Gore M and Lemke G: Structure, expression, and activity of tyro 3, a neural adhesion-related receptor tyrosine kinase. Oncogene 9(9): 2567-2578, 1994. PMID: 8058320.

45 Shao H, Lauffenburger D and Wells A: Tyro3 carboxyl terminal region confers stability and contains the autophosphorylation sites. Biochem Biophys Res Commun 490(3): 1074-1079, 2017. PMID: 28668391. DOI: 10.1016/j.bbrc.2017.06.168

46 Odero MD, Grand FH, Iqbal S, Ross F, Roman JP, Vizmanos JL, Andrieux J, Laï JL, Calasanz MJ and Cross NC: Disruption and aberrant expression of hmga2 as a consequence of diverse chromosomal translocations in myeloid malignancies. Leukemia 19(2): 245-252, 2005. PMID: 15618963. DOI: 10.1038/sj.leu. 2403605

47 Ho J, Peters T, Dickson BC, Swanson D, Fernandez A, FrovaSeguin A, Valentin MA, Schramm U, Sultan M, Nielsen TO and Demicco EG: Detection of csf1 rearrangements deleting the 3' utr in tenosynovial giant cell tumors. Genes Chromosomes Cancer 59(2): 96-105, 2020. PMID: 31469468. DOI: 10.1002/gcc.22807

48 Panagopoulos I, Brandal P, Gorunova L, Bjerkehagen B and Heim S: Novel csf1-s100a10 fusion gene and csf1 transcript identified by rna sequencing in tenosynovial giant cell tumors. Int J Oncol 44(5): 1425-1432, 2014. PMID: 24604026. DOI: $10.3892 /$ ijo.2014.2326

49 van IDG, de Jong D, Romagosa C, Picci P, Benassi MS, Gambarotti M, Daugaard S, van de Sande M, Szuhai K and Bovée JV: Fusion events lead to truncation of fos in epithelioid hemangioma of bone. Genes Chromosomes Cancer 54(9): 565574, 2015. PMID: 26173738. DOI: 10.1002/gcc.22269

50 Kristjánsdóttir K, Fogarty EA and Grimson A: Systematic analysis of the hmga2 3' utr identifies many independent regulatory sequences and a novel interaction between distal sites. Rna 21(7): 1346-1360, 2015. PMID: 25999317. DOI: 10.1261/rna.051177.115

51 Mayr C: What are 3' utrs doing? Cold Spring Harb Perspect Biol 11(10), 2019. PMID: 30181377. DOI: 10.1101/cshperspect. a034728

52 Hromas R, Busse T, Carroll A, Mack D, Shopnick R, Zhang DE, Nakshatri $\mathrm{H}$ and Richkind K: Fusion aml1 transcript in a radiation-associated leukemia results in a truncated inhibitory aml1 protein. Blood 97(7): 2168-2170, 2001. PMID: 11264187. DOI: 10.1182/blood.v97.7.2168

53 Ramsey H, Zhang DE, Richkind K, Burcoglu-O'Ral A and Hromas R: Fusion of aml1/runx1 to copine viii, a novel member of the copine family, in an aggressive acute myelogenous leukemia with $\mathrm{t}(12 ; 21)$ translocation. Leukemia 17(8): 16651666, 2003. PMID: 12886257. DOI: 10.1038/sj.leu.2403048

54 Rodriguez-Perales S, Torres-Ruiz R, Suela J, Acquadro F, Martin MC, Yebra E, Ramirez JC, Alvarez S and Cigudosa JC: Truncated runx 1 protein generated by a novel $\mathrm{t}(1 ; 21)(\mathrm{p} 32 ; \mathrm{q} 22)$ chromosomal translocation impairs the proliferation and differentiation of human hematopoietic progenitors. Oncogene 35(1): 125-134, 2016. PMID: 25798834. DOI: 10.1038/onc.2015.70

55 Migliazza A, Lombardi L, Rocchi M, Trecca D, Chang CC, Antonacci R, Fracchiolla NS, Ciana P, Maiolo AT and Neri A: Heterogeneous chromosomal aberrations generate 3' truncations 
of the nfkb2/lyt-10 gene in lymphoid malignancies. Blood 84(11): 3850-3860, 1994. PMID: 7949142.

56 Torkildsen S, Brunetti M, Gorunova L, Spetalen S, Beiske K, Heim $S$ and Panagopoulos I: Rearrangement of the chromatin organizer special at-rich binding protein 1 gene, satb1, resulting from a $\mathrm{t}(3 ; 5)(\mathrm{p} 24 ; \mathrm{q} 14)$ chromosomal translocation in acute myeloid leukemia. Anticancer Res 37(2): 693-698, 2017. PMID: 28179318. DOI: 10.21873/anticanres.11365

57 Belloni E, Trubia M, Mancini M, Derme V, Nanni M, Lahortiga I, Riccioni R, Confalonieri S, Lo-Coco F, Di Fiore PP and Pelicci PG: A new complex rearrangement involving the etv6, loc115548, and mn1 genes in a case of acute myeloid leukemia. Genes Chromosomes Cancer 41(3): 272-277, 2004. PMID: 15334551. DOI: $10.1002 / \mathrm{gcc} .20081$

58 Micci F, Panagopoulos I, Haugom L, Andersen HK, Tjønnfjord GE, Beiske $\mathrm{K}$ and Heim S: T(3;21)(q22;q22) leading to truncation of the ryk gene in atypical chronic myeloid leukemia. Cancer Lett 277(2): 205-211, 2009. PMID: 19168282. DOI: $10.1016 /$ j.canlet.2008.12.016
59 Abe A, Yamamoto Y, Katsumi A, Yamamoto H, Okamoto A, Inaguma $\mathrm{Y}$, Iriyama $\mathrm{C}$, Tokuda $\mathrm{M}$, Okamoto $\mathrm{M}$, Emi $\mathrm{N}$ and Tomita A: Truncated runx 1 generated by the fusion of runx 1 to antisense grik 2 via a cryptic chromosome translocation enhances sensitivity to granulocyte colony-stimulating factor. Cytogenet Genome Res, 2020. PMID: 32544910. DOI: 10.1159/000508012

60 Rasighaemi P, Liongue C, Onnebo SM and Ward AC: Functional analysis of truncated forms of etv6. Br J Haematol 171(4): 658662, 2015. PMID: 25850516. DOI: 10.1111/bjh.13428

61 Mitelman Database of Chromosome Aberrations and Gene Fusions in Cancer, 2020. Available at: https://mitelmandatabase.isb-cgc.org/ [Last accessed April 15, 2020]

Received July 24, 2020

Revised September 15, 2020

Accepted September 16, 2020 